\title{
Low LDH Level
}

National Cancer Institute

\section{Source}

National Cancer Institute. Low LDH Level. NCI Thesaurus. Code C162102.

A lower than average level of lactate dehydrogenase in a sample. 